\title{
Microplastic Ingestion by Daphnia Magna and its Enhancement on Algal Growth
}

\author{
Patrick M. Canniff \\ Loyola University Chicago \\ Tham C. Hoang \\ Loyola University Chicago, thoang@luc.edu
}

Follow this and additional works at: https://ecommons.luc.edu/ies_facpubs

Part of the Environmental Indicators and Impact Assessment Commons, and the Environmental Monitoring Commons

Author Manuscript

This is a pre-publication author manuscript of the final, published article.

\section{Recommended Citation}

Canniff, Patrick M. and Hoang, Tham C.. Microplastic Ingestion by Daphnia Magna and its Enhancement on Algal Growth. Science of the Total Environment, 633, : 500-507, 2018. Retrieved from Loyola eCommons, School of Environmental Sustainability: Faculty Publications and Other Works, http://dx.doi.org/10.1016/j.scitotenv.2018.03.176

This Article is brought to you for free and open access by the Faculty Publications and Other Works by Department at Loyola eCommons. It has been accepted for inclusion in School of Environmental Sustainability: Faculty Publications and Other Works by an authorized administrator of Loyola eCommons. For more information, please contactecommons@luc.edu. c) () $\odot$

This work is licensed under a Creative Commons Attribution-Noncommercial-No Derivative Works 3.0 License. (C) Elsevier B.V. 2018 


\section{Microplastic ingestion by Daphnia magna and its enhancement on algal growth}

\section{Patrick M. Cannif}

Tham $\underline{\text { C. Hoang }}$

thoang@luc.edu

Institute of Environmental Sustainability, Loyola University Chicago, 1032 W Sheridan Road, Chicago, IL 60660z6, United States

${ }^{*}$ Corresponding author

Editor: D. Barcelo

\section{Abstract}

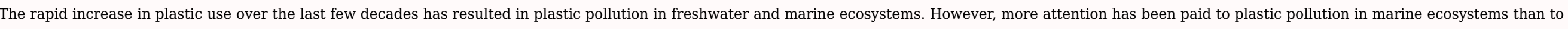

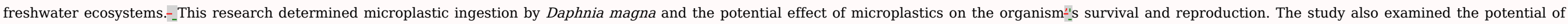

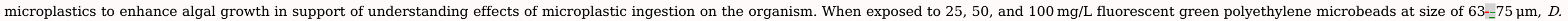

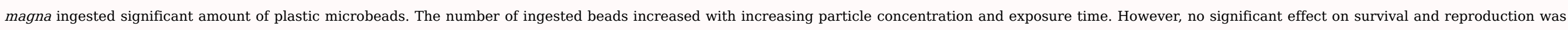

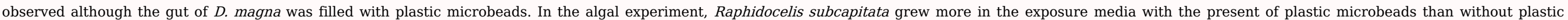

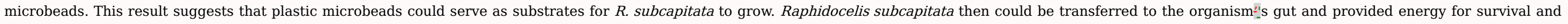

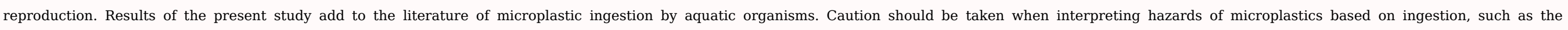
measurement unit and the presence of algae in the environment.

Keywords: Microplastics; fFluorescent green polyethylene microbeads; microplastic ingestion; Daphnia magna; Selenastrum capricornutum; Raphidocelis subcapitata

\subsection{Introduction}

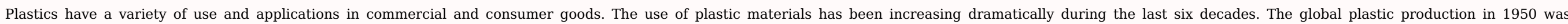

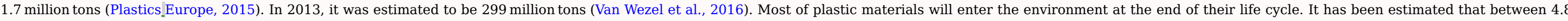

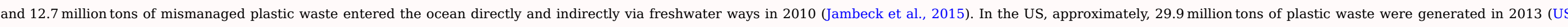

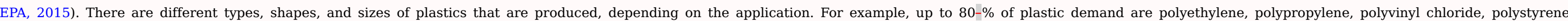

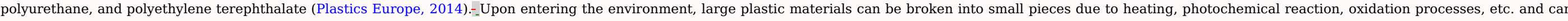

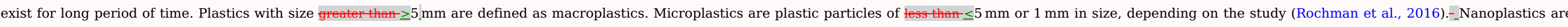
plastic particles with size ranging from $1 \mu \mathrm{m}$ to $100 \mathrm{~nm}$ (Rochman et al., 2016).

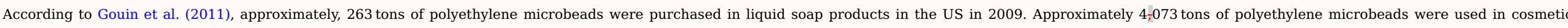

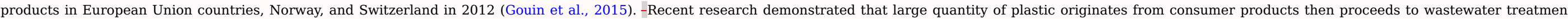

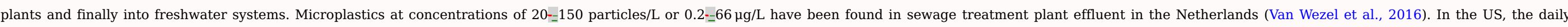

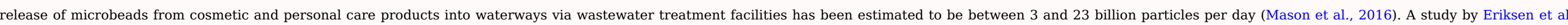

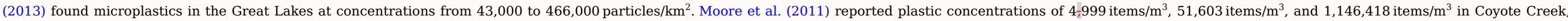
San Gaabriel River, and Los Angeles River, respectively. The persistence of plastics, especially micro- and nano-plastics in the natural environment poses potential risks to living organisms. 


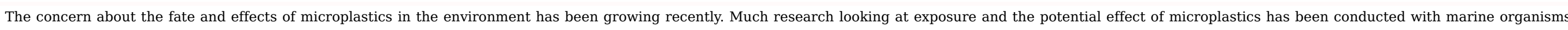

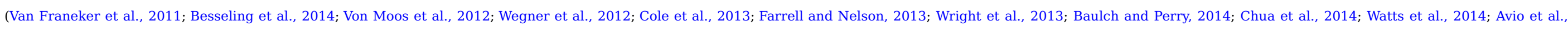

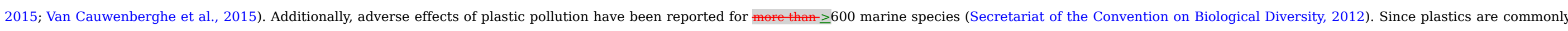

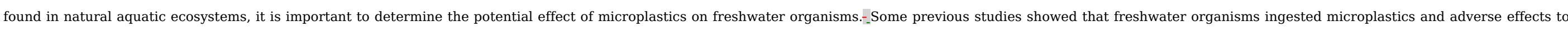

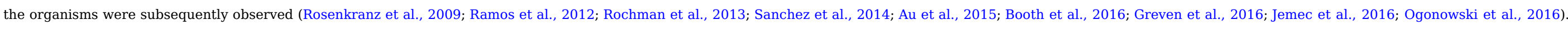

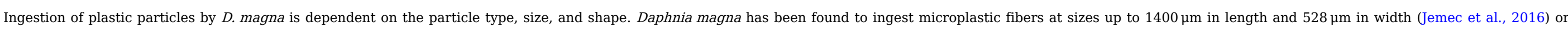

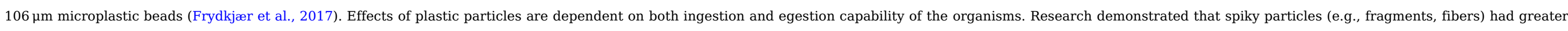
effect potential than do smooth particles (i.e., spherical beads) because egestion of spiky particles is more difficult than egestion of smooth particles (Frydkjær et al., 2017).

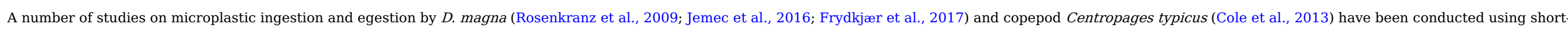

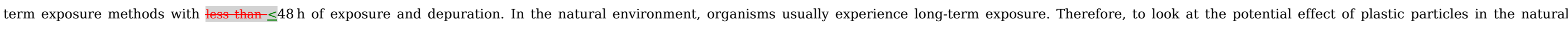

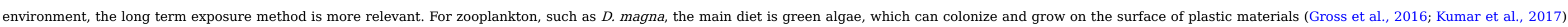

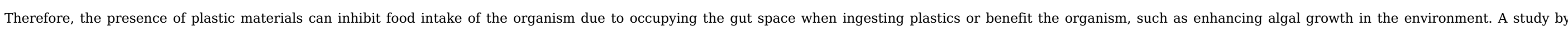

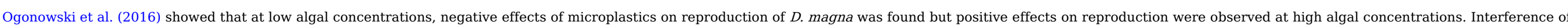
plastic particles on food intake by $D$. magna is not fully understood.

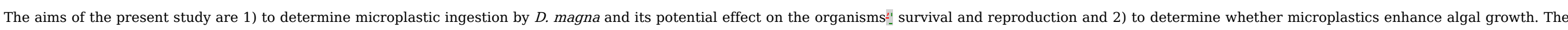

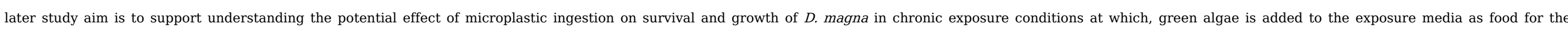
organism.

\section{Materials and Mmethods \\ 2.1.2.1 Organisms}

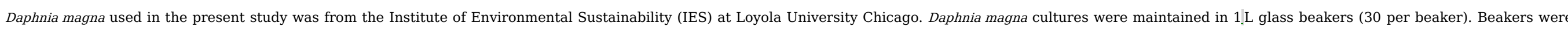

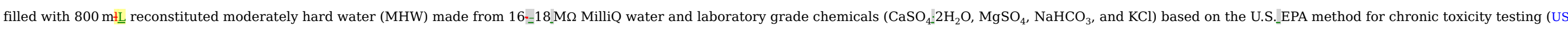

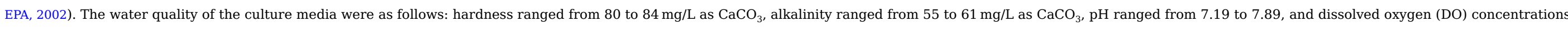

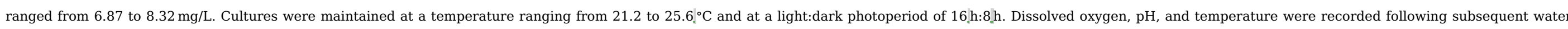

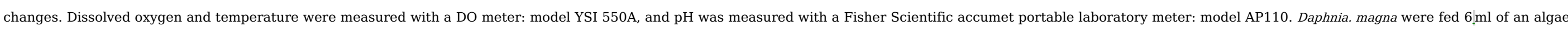

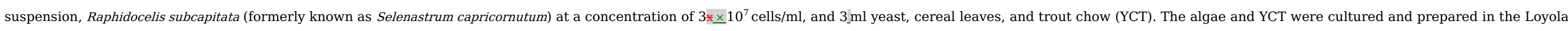
IES based on the U.S. EPA Method (US EPA, 2002).

\subsubsection{Experimental design and procedures}

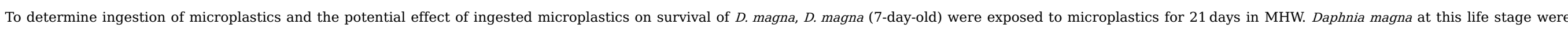

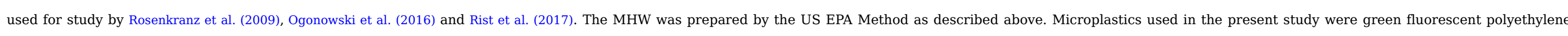

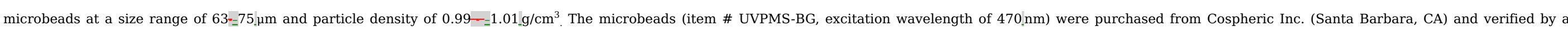

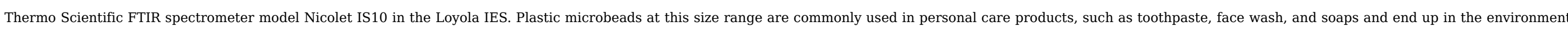

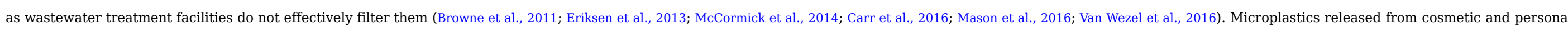

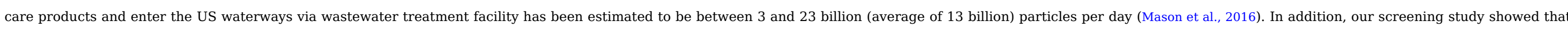

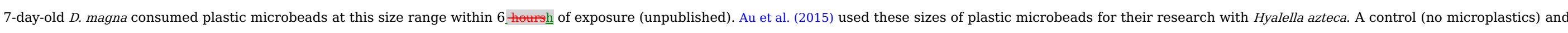

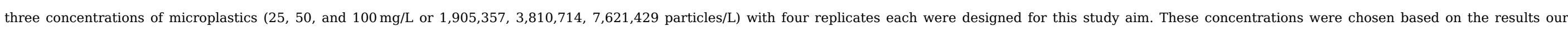




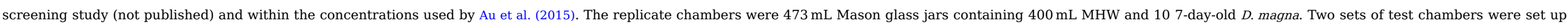

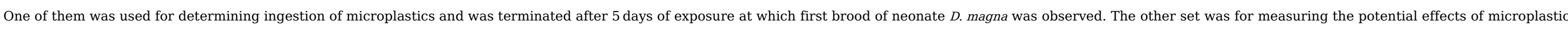

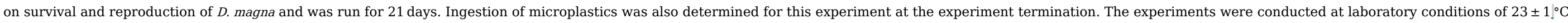
and light:dark $=16 \mathrm{~h}: 8 \mathrm{~h}$ in the Ecotoxicology and Risk Assessment Laboratory of the Loyola IES.

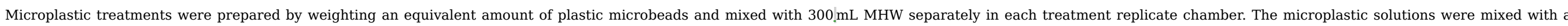

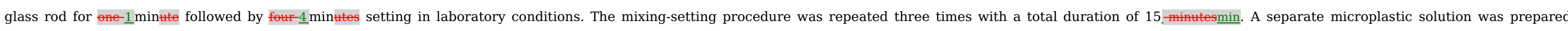

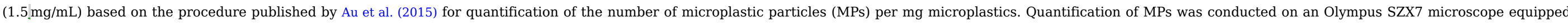

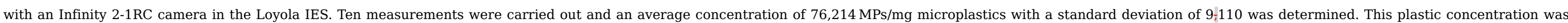

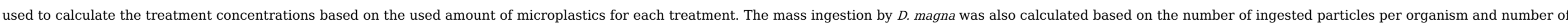

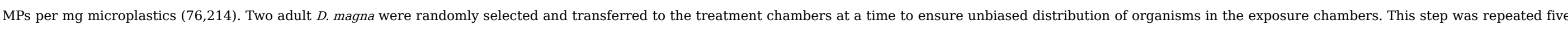

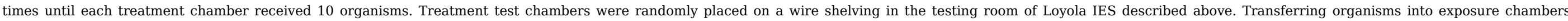
initiated the experiment.

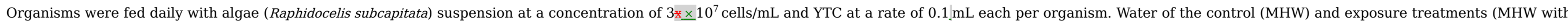

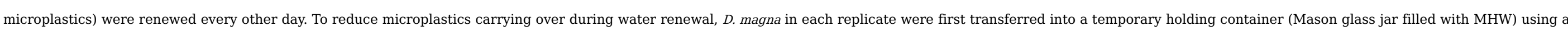

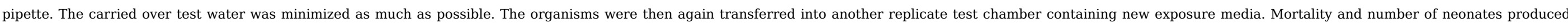

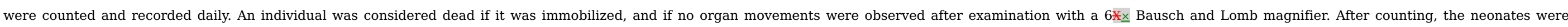
removed from the test chambers.

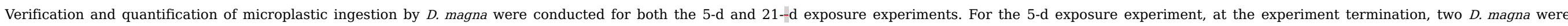

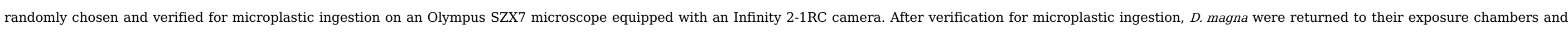

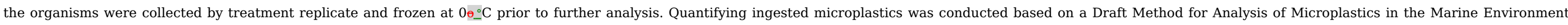

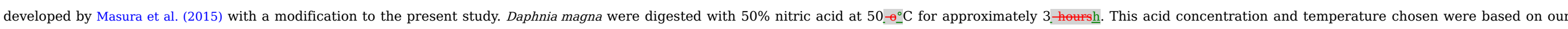

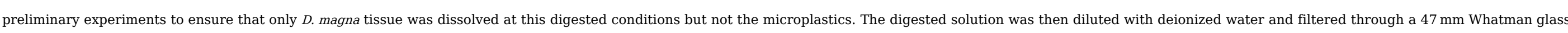

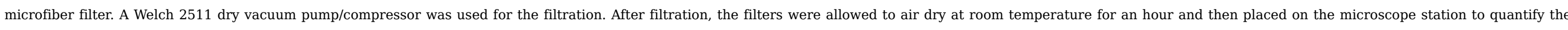
number of MPs. Similar procedure was used for quantifying microplastics in D. magna from 21-d exposure experiment.

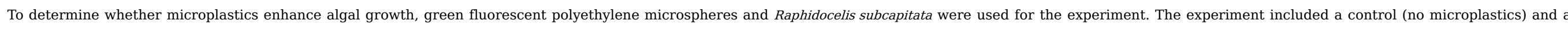

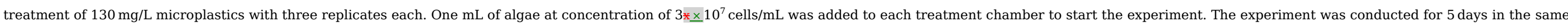

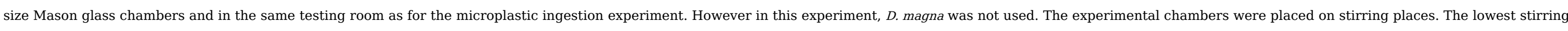

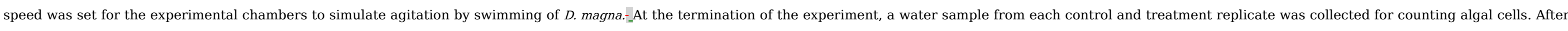

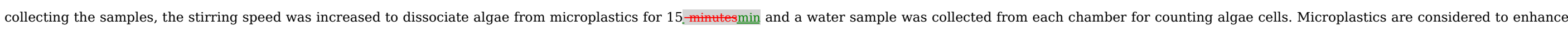

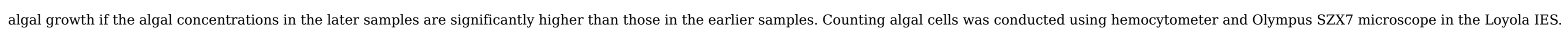

\subsubsection{Data analysis}

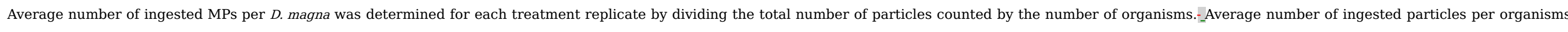

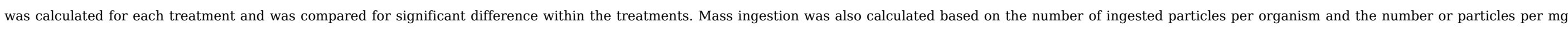
plastics determined in the present study $(76,214 \mathrm{MPs} / \mathrm{mg})$. Statistical analysis was also performed for the mass ingestion results. 


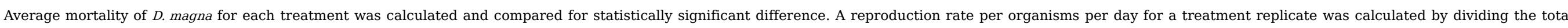

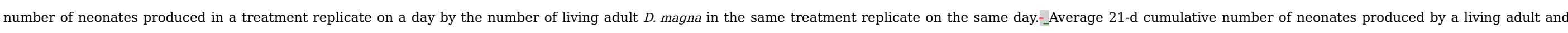
average reproductive rate per day for each treatment were calculated and compared for significantly difference between the treatments.

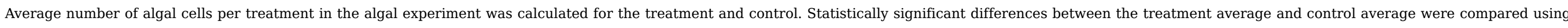

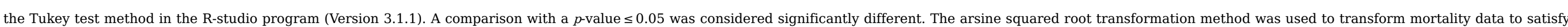
the assumption of homogeneous variance and normal distribution. Other data met the assumption of homogenous variance and normal distribution, therefore, no transformation was needed.

\section{3 Results}

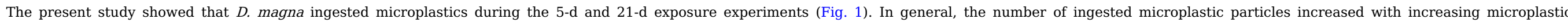

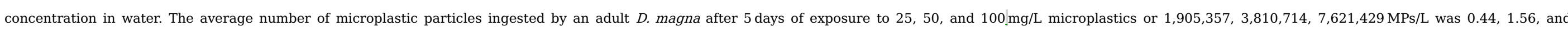

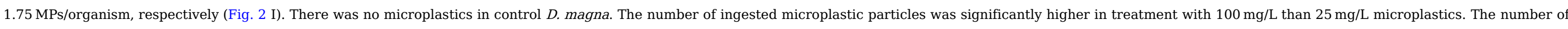

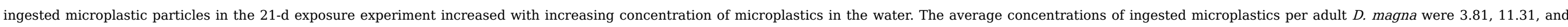

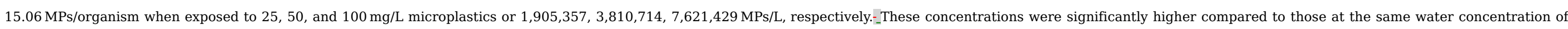

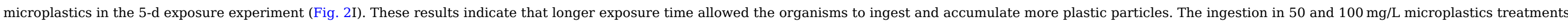
were significantly higher than the ingestion in $25 \mathrm{mg} / \mathrm{L}$ microplastics treatment. There was no significant difference between the ingestion in 50 and $100 \mathrm{mg} / \mathrm{L}$ microplastics (Fig. $2 \mathrm{I}$ ).

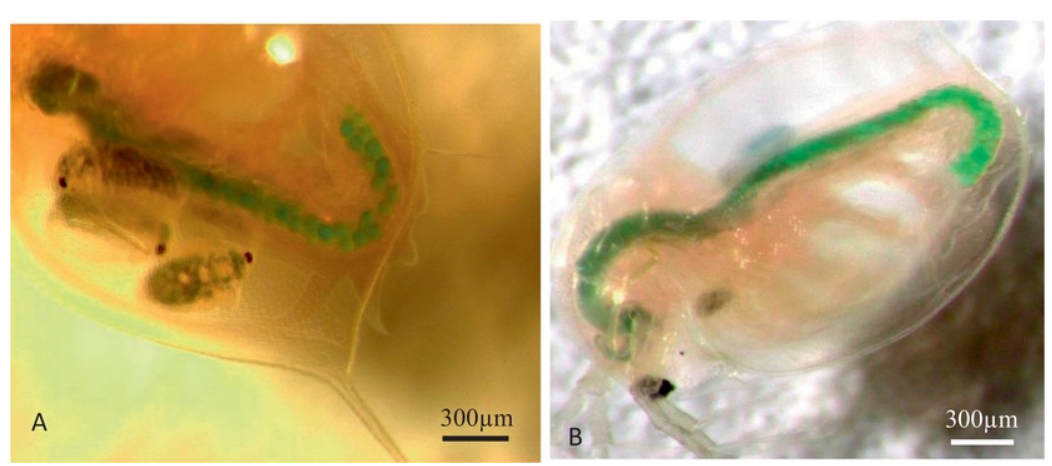

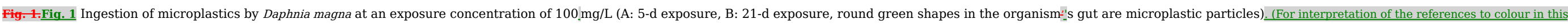
figure legend, the reader is referred to the web version of this article.)

alt-text: Fig. 1 

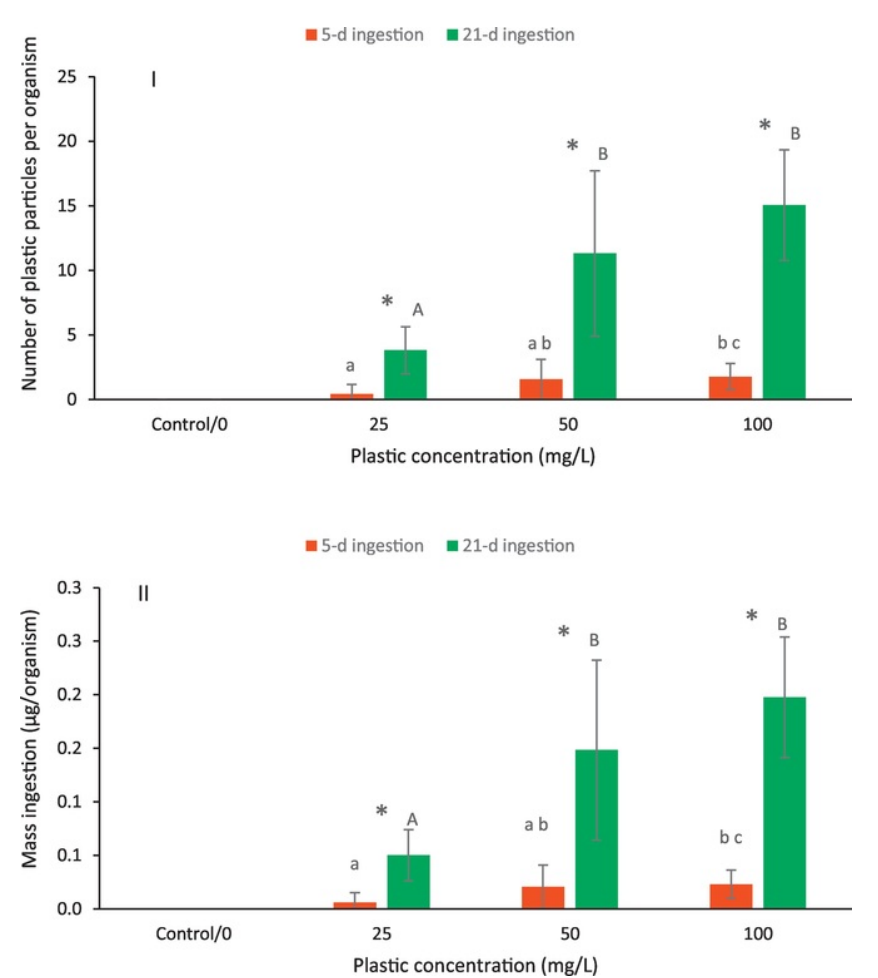

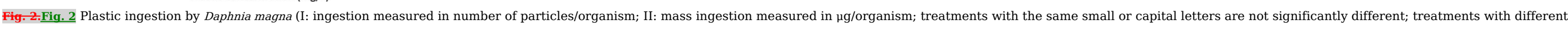

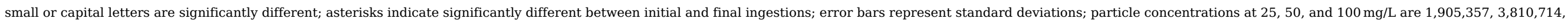

7,621,429 MPs/L, respectively):

\section{alt-text: Fig. 2}

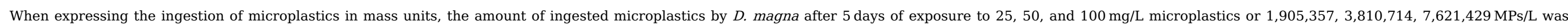

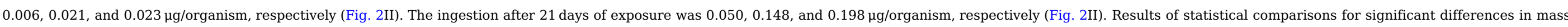
ingestion between and within the treatments were similar to the ingestion in particles per organism.

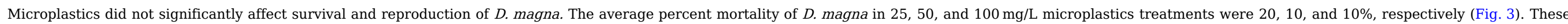

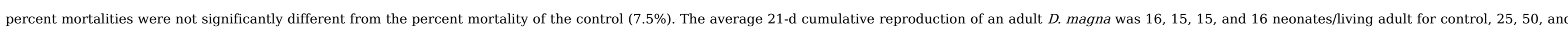

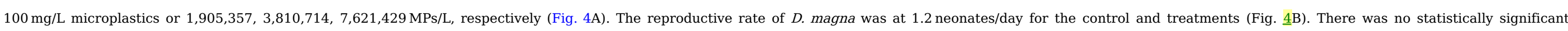
differences between the reproductive measurements of the control and exposure treatments. 


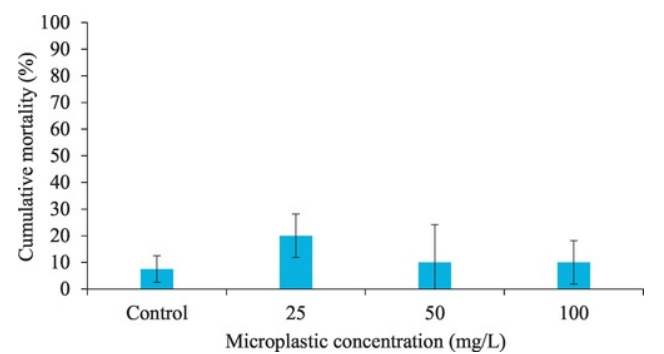

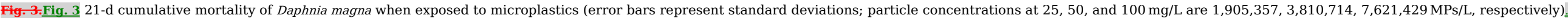
alt-text: Fig. 3
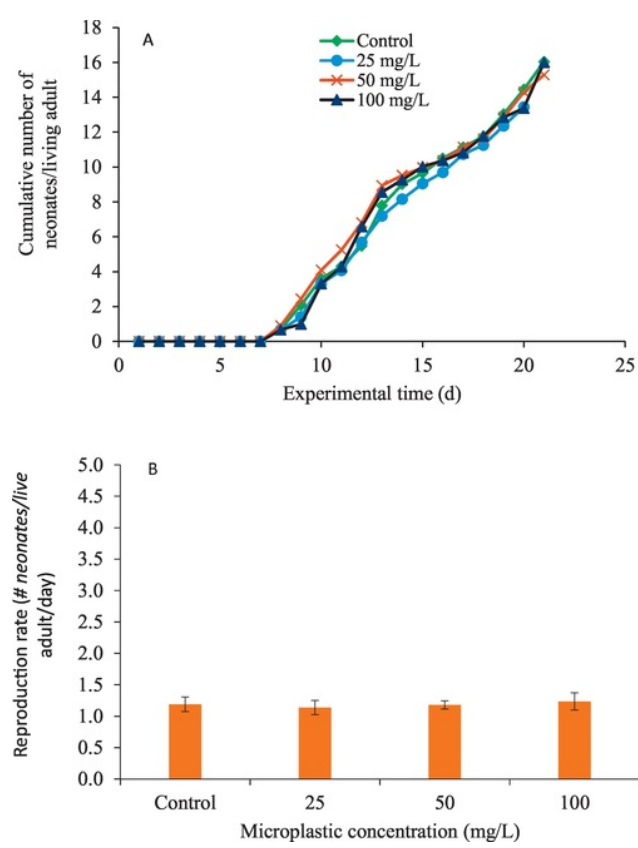

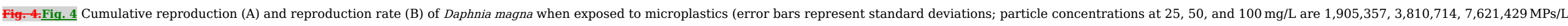
respectively)]

\section{alt-text: Fig. 4}

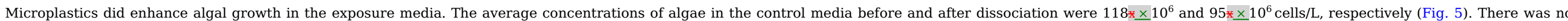

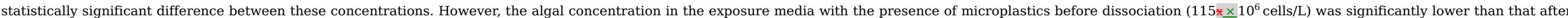

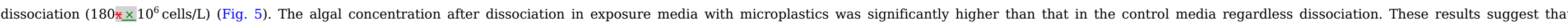
microplastics could potentially serve as substrates for algae to grow. 


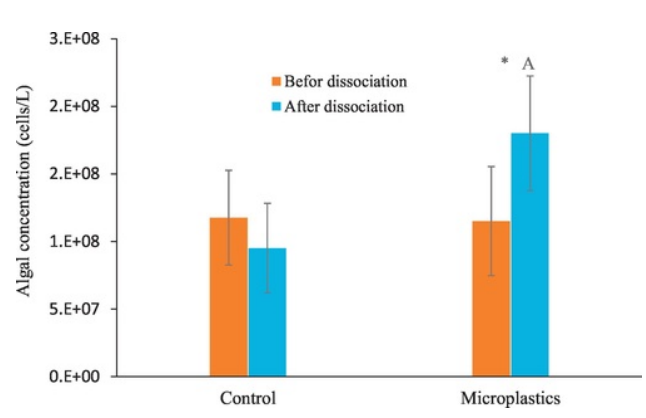

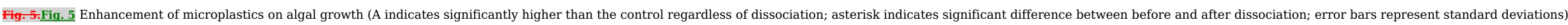
alt-text: Fig. 5

\section{4. $\underline{4}$ Discussion}

\subsubsection{Microplastic ingestion: particle size dependence and importance of measurement unit}

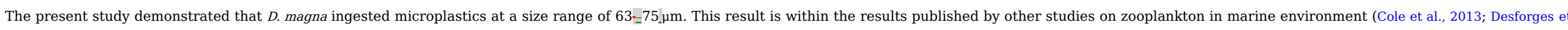

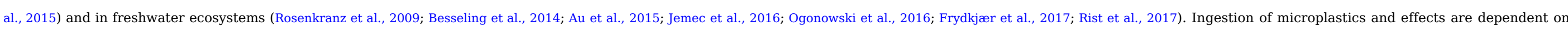

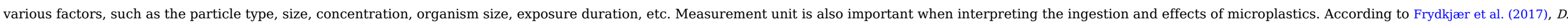

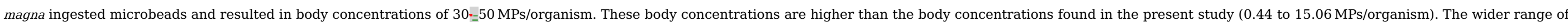

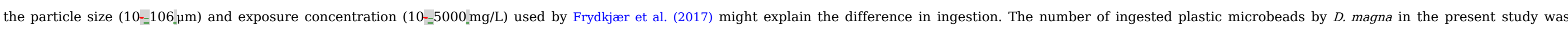

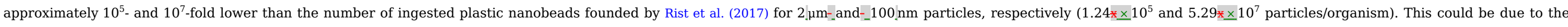

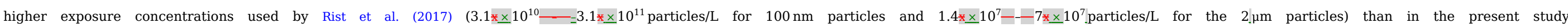

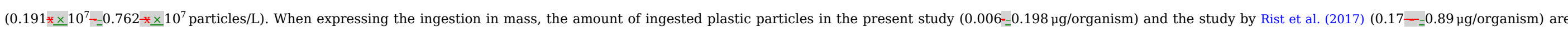

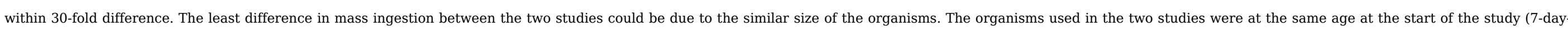

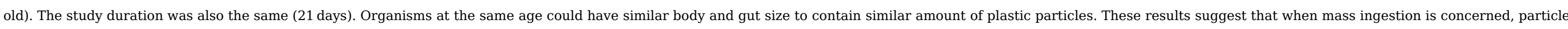

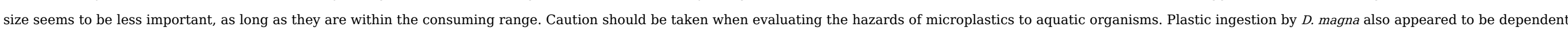

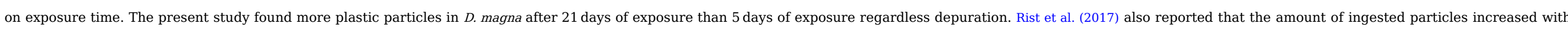

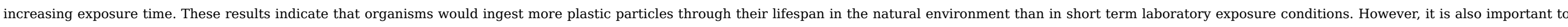
mention that plastic concentrations used in laboratory research are usually higher than the environmental concentrations (Lenz et al., 2016).

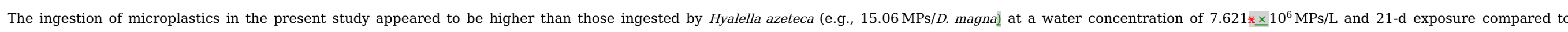

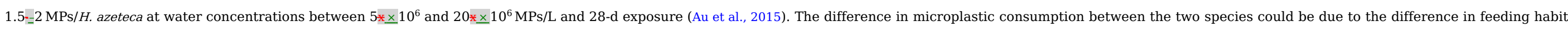

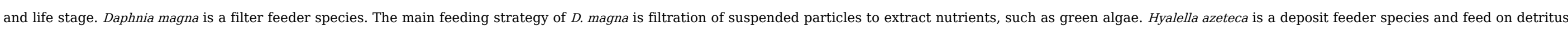

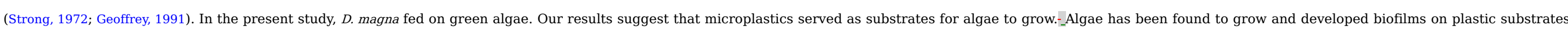

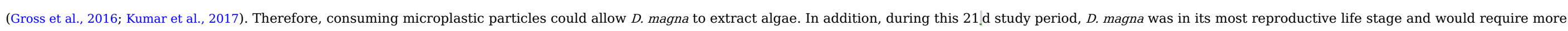

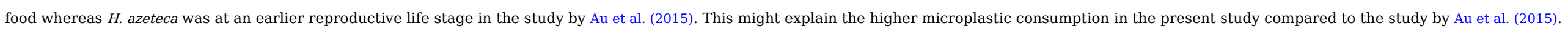

\subsubsection{Reproduction: role of algal growth on plastics and particle shape and excretion}

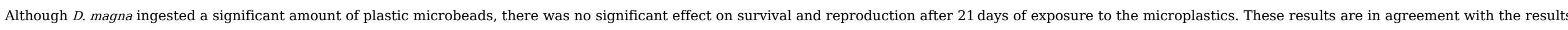

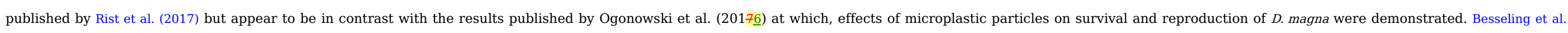




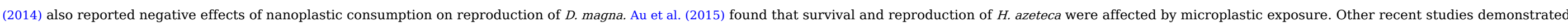

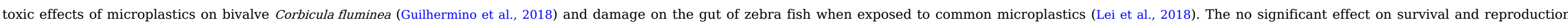
found in the present study suggests that the organisms obtained sufficient energy for survival and reproduction.

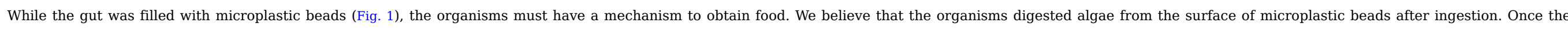

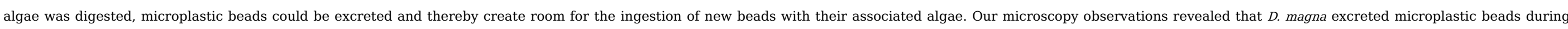

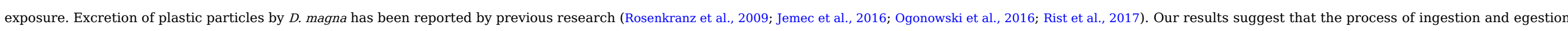

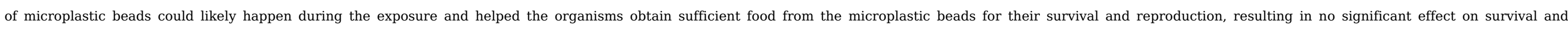
reproduction after 21 days of exposure.

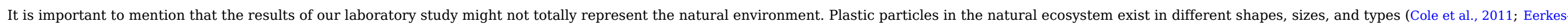

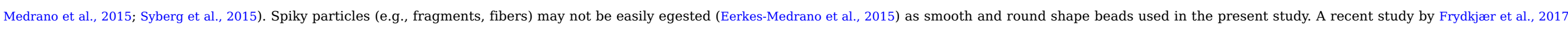

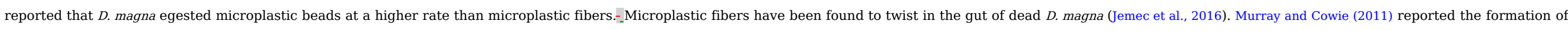

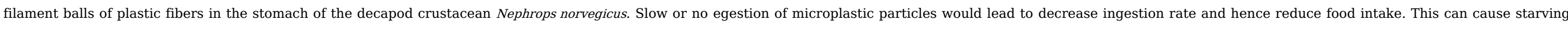

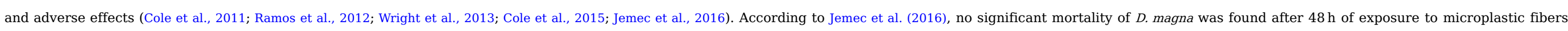

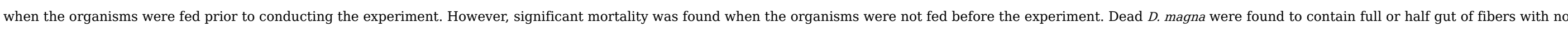

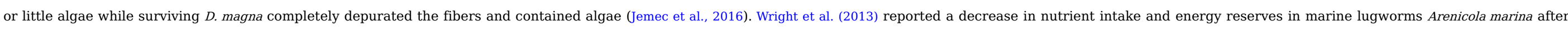
consumption of microplastics. Another study suggested a reduction in feeding in field collected fish (Eugerres brasilianus) because of ingestion of plastic fragments (Ramos et al., 2012).

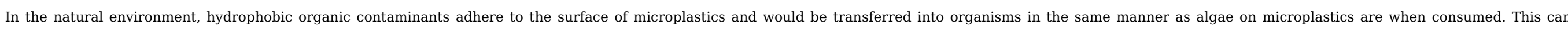

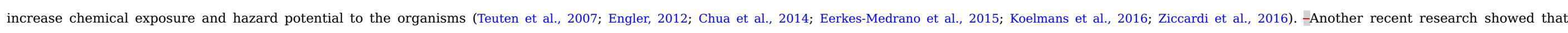
microplastic fibers adsorbed phenanthrene and inhibited mobility of D. magna (Frydkjær et al., 2017).

\section{5.}

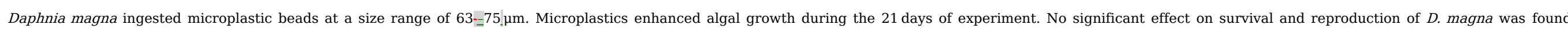

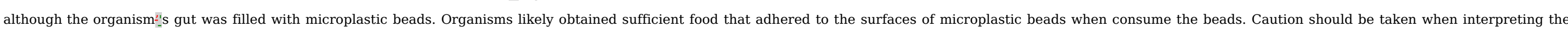

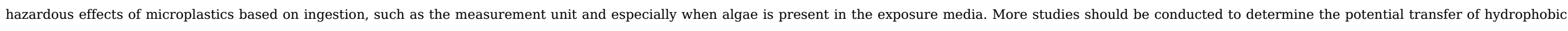
organic contaminants that adhere to the surface of plastic particles and to ascertain their effects on bioaccumulation, survival, and reproductive effect potential to aquatic organisms.

\section{Acknowledgement}

The authors are grateful to Madeline Wrey for her assistance with the experiment. Financial support for this study was from a Carbon Fellowship of Loyola University Chicago.

\section{References}

Au S.Y., Bruce T.F., Bridges W.C. and Klaine S.J., Responses of Hyalella azteca to acute and chronic microplastic exposures, Environ. Toxicol. Chem. 34 (11), 2015 , 2564-2572.

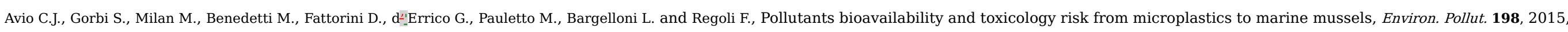

$211-222$.

Baulch S. and Perry C., Evaluating the impacts of marine debris on cetaceans, Mar. Pollut. Bull. 80, 2014, 210-221.

Besseling E., Wang B., Lurling M. and Koelmans A., Nanoplastic affects growth of S. obliquus and reproduction of D. magna, Environ. Sci. Technol. 48, 2014, 12336-12343.

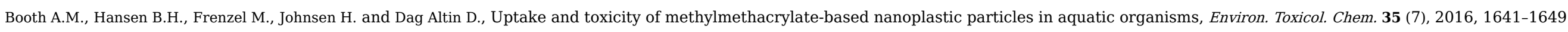


Browne M.A., Crump P., Niven S.J., Teuton E., Tonkin A., Galloway T. and Thompson R.C., Accumulation of microplastic on shorelines worldwide, Environ. Sci. Technol. 45, 2011, 9175-9179.

Carr S.A., Liu J., Arnold G. and Tesoro A.G., Transport and fate of microplastic particles in wastewater treatment plants, Water Res. 91, 2016, 174-182.

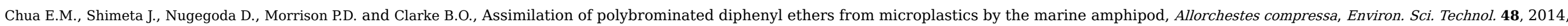
8127-8134.

Cole M., Lindeque P., Halsband C. and Galloway T.S., Microplastics as contaminants in the marine environment: Aa review, Mar. Pollut. Bull. 62 (12), $2011,2588-2597$.

Cole M., Lindeque P., Fileman E., Halsband C., Goodhead R., Moger J. and Galloway T.ST.S., Microplastic ingestion by zooplankton, Environ. Sci. Technol. 47, $2013,6646-6655$.

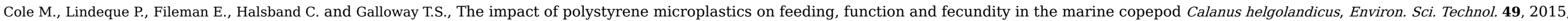
1130-1137, https://doi.org/10.1021/es504525u.

Desforges J.P.W., Moira Galbraith M. and Ross P.S., Ingestion of microplastics by zooplankton in the northeast pacific ocean, Arch. Environ. Contam. Toxicol. 69, 2015, 320-330.

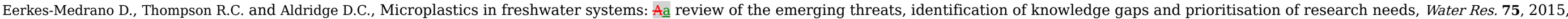
63-82.

Engler R.E., The complex interaction between marine debris and toxic chemicals in the ocean, Environ. Sci. Technol. 46, 2012, 12302-12315, https://doi.org/10.1021/es3027105.

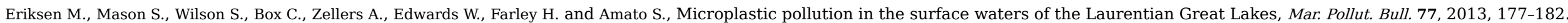

Farrell P. and Nelson K., Trophic level transfer of microplastic: Mytilus edulis (L.) to Carcinus maenas (L.), Environ. Pollut. 77, 2013, 1-3.

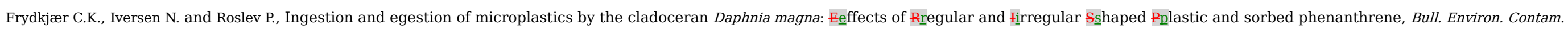
Toxicol. 99, 2017, 655-661, https://doi.org/10.1007/s00128-017-2186-3.

Geoffrey FE., Functional morphology and the adaptive radiation of the Daphniidae (Branchiopoda: Anomopoda), Philos. Trans. R. Soc. Lond. Ser. B Biol. Sci. 331 (1259), 1991, 1-99.

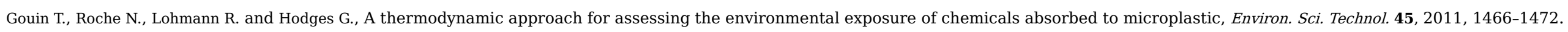

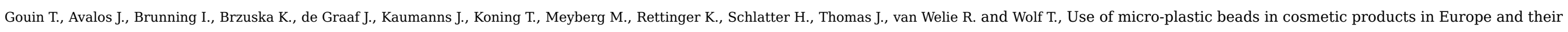
estimated emissions to the North Sea environment. SOFW, Journal 141, 2015, 3.

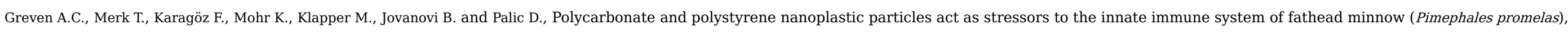
Environ. Toxicol. Chem. 35 (12), 2016, 3093-3100.

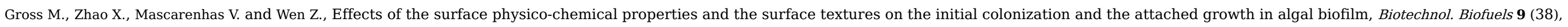
2016, 2-14.

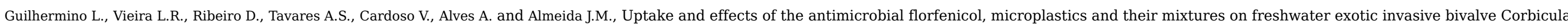
fluminea, Sci. Total Environ. 622-623, 2018, 1131-1142.

Jambeck J.R., Geyer R., Wilcox C., Siegler T.R., Perryman M., Andrady A., Narayan R. and Law K.L., Plastic waste inputs from land into the ocean, Science 347, 2015 , 768-771.

Jemec A., Horvat P., Kunej U., Bele M. and Kr_zan A., Uptake and effects of microplastic textile fibers on freshwater crustacean Daphnia magna, Environ. Pollut. 219, 2016, 201-209, https://doi.org/10.1016/j.envpol.2016.10.037.

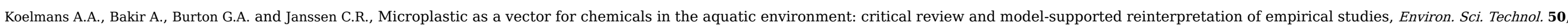
2016, 3315-3326, https://doi.org/10.1021/acs.est.5b06069. 
Kumar R.V., Kanna G.R. and Elumalai S., Biodegradation of polyethylene by green photosynthetic microalgae, J. Bioremed. Biodegr. 8, 2017, , 381https://doi.org/10.4172/2155-6199.1000381.

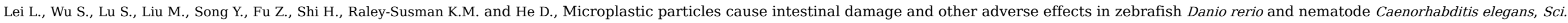
Total Environ. 619-620, 2018, 1-8.

Lenz R., Endersa K. and Nielsena T.G., Microplastic exposure studies should be environmentally realistic, PNAS 113 (29), 2016, 4121-4122.

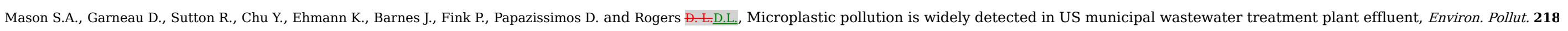
2016, 1045-1054, https://doi.org/10.1016/j.envpol.2016.08.056.

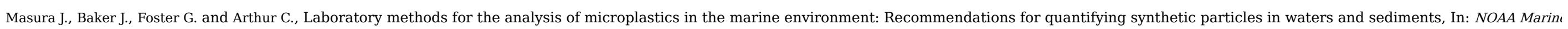
Debris Division 1305 East-West Highway Silver Spring, MD 20910 USA, 2015.

McCormick A., Hoellein T.J., Mason S.A., Schluep J. and Kelly J.J., Microplastic is an abundant and distinct microbial habitat in an urban river, Environ. Sci. Technol. 48, 2014 , 11863-11871.

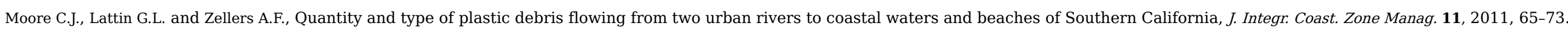

Murray F. and Cowie P. R.P.R., Plastic contamination in the decapod crustacean Nephrops norvegicus (Linnaeus, 1758), Mar. Pollut. Bull. 62 (6), $2011,1207-1217$.

Ogonowski M., Schür C., Jarsen Å. and Gorokhova E., The effects of natural and anthropogenic microparticles on individual fitness in Daphnia magna, PLoS One 11, 2016, , e0155063https://doi.org/10.1371/journal.pone.0155063.

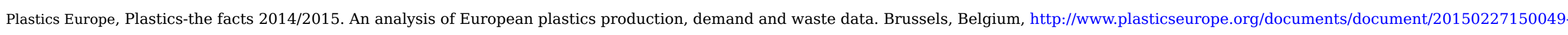
final_plastics_the_facts_2014_2015_260215.pdf, 2014, Accessed 6 January 2018.

Plastics Europe, Plastics-the facts 2014/15. An analysis of European plastics production, demand and waste data, http://www.plasticseurope.org/documents/document/20151216062602-

plastics_the_facts_2015_final_30pages_14122015.pdf, 2015, Accessed 6 January 2018.

Ramos J.A.A., Barletta M. and Costa M.F., Ingestion of nylon threads by Gerreidae while using a tropical estuary as foraging grounds, Aquat. Biol. 17, 2012 , 29-34.

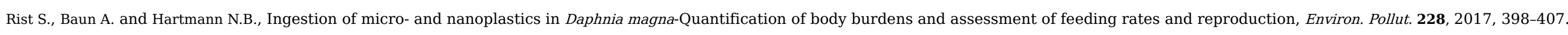

Rochman C.M., Hoh E., Kurobe T. and Teh S.J., Ingested plastic transfers hazardous chemicals to fish and induces hepatic stress, Sci. Rep. 3, 2013,3263 , https://doi.org/10.1038/srep03263.

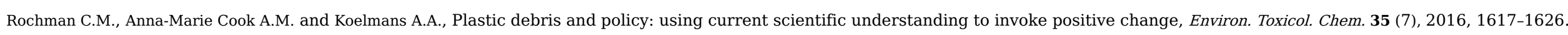

Rosenkranz P., Chaudhry Q., Stone V. and Fernandes T.F., A comparison of nanoparticle and fine particle uptake by Daphnia magna, Environ. Toxicol. Chem. 28 (10), 2009 , 2142-2149.

Sanchez W., Bender C. and Porcher J.M., Wild gudgeons (Gobio gobio) from French rivers are contaminated by microplastics: preliminary study and first evidence, Environ. Res. 128, 2014, 98-100.

Secretariat of the Convention on Biological Diversity, Marine Biodiversity-One Ocean, Many Worlds of Life, Montreal, Canada, 2012.

Strong D.R., Life history variation among populations of an amphipod (Hyalella azteca), Ecology 53 (6), 1972, 1103-1111.

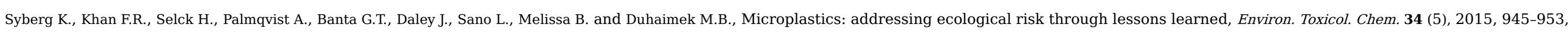
https://doi.org/10.1002/etc.2914.

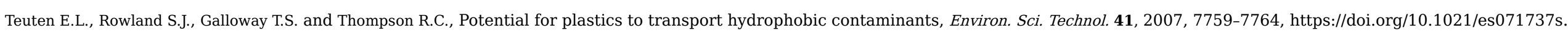

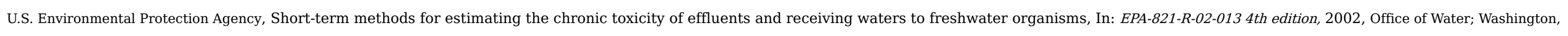
DC.

US Environmental Protection Agency, Advancing sustainable materials management: 2013 fact sheet, In: EPA 530-R-15-003. Washington, DC, 2015. 


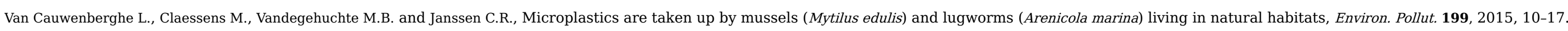

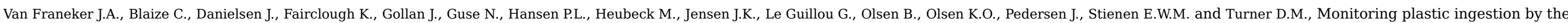
northern fulmar Fulmarus glacialis in the North Sea, Environ. Pollut. 159, 2011, 2609-2615.

Van Wezel A., Caris I. and Koolsy S.A.E., Release of primary microplastics from consumer products to wastewater in the Netherlands, Environ. Toxicol. Chem. 35 (7), 2016, 1627-1631.

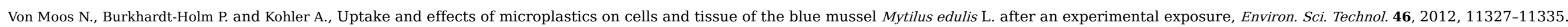

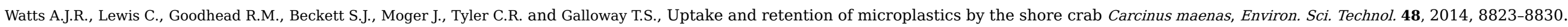

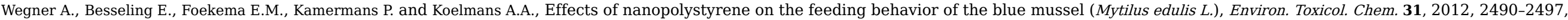
https://doi.org/10.1002/etc.1984.

Wright S.L., Thompson R.C. and Galloway T.S., The physical impacts of microplastics on marine organisms: Aạ review, Environ. Pollut. 178, 2013, 483-492.

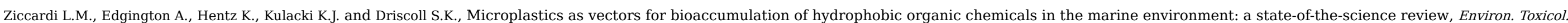
Chem. 35 (7), 2016, 1667-1676.

\section{Graphical abstract}

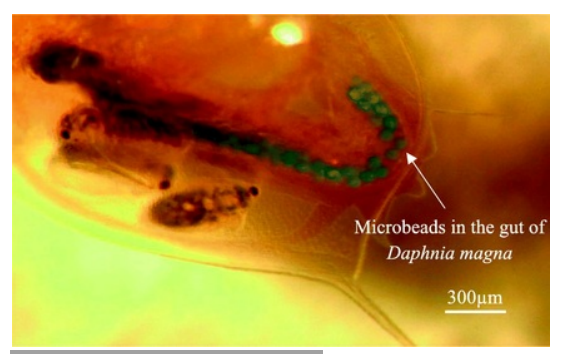

alt-text: Unlabelled Image

\section{Highlights}

- Daphnia magna ingested plastic microbeads at size of 63--75] $\mathrm{mm}_{\text {, }}$

- Body concentrations of microplastics increased with exposure time!

- No significant effect on survival and reproduction of $D$. magna was found.

- Microplastics enhanced algae growth.

- A procedure for quantifying microplastics in $D$. magna's gut was presented

\section{Queries and Answers}

Query: 


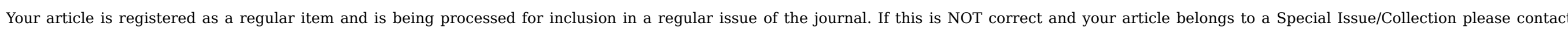
p.das@elsevier.com immediately prior to returning your corrections.

\section{Answer: Yes}

Query:

Please confirm that given names and surnames have been identified correctly and are presented in the desired order, and please carefully verify the spelling of all authors' names.

Answer: Yes

Query:

The author names have been tagged as given names and surnames (surnames are highlighted in teal color). Please confirm if they have been identified correctly.

\section{Answer: Yes}

Query:

The country name "United States" has been inserted for the authors' affiliation. Please check, and correct if necessary.

Answer: It is OK

Query:

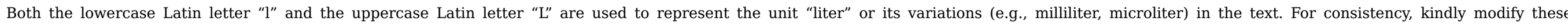
occurrences so that only one format is used throughout the article.

Answer: use L

Query:

Would you consider changing the citation "Fig. B" to "Fig. 4B"? Please check, and amend as necessary.

Answer: changed

Query:

An extra closing parenthesis has been inserted. Please check and confirm if correct.

Answer: Yes

Query:

Citation "Ogonowski et al. (2017)" has not been found in the reference list. Please supply full details for this reference.

Answer: It is 2016. We already changed it

Query:

Please provide the corresponding grant number(s) for the following grant sponsor(s): "Loyola University Chicago".

Answer: There was no number for this grant. 